\title{
\#chatsafe for lærere
}

\author{
Av Helene Astrup
}

\begin{abstract}
\#chatsafe for lærere er utviklet for å gjøre det enklere for lærere å gi råd til ungdommer og bistå til sikker kommunikasjon om selvmord på nettet. Her finner du ressursene til bruk i undervisningen; de er utviklet i samarbeid med ungdom.
\end{abstract}

VEILEDEREN INNEHOLDER råd om hvordan man kan kommunisere trygt med ungdom om selvmord på nettet og hvordan man kan bistå ungdom som er bekymret for noen eller som onsker å engasjere seg i selvmordsrelatert innhold på nettet. Her finner du ressursene:

\#chatsafe for lærere, \#chatsafe for ungdom og Topp 10-tips: https://www.med.uio.no/klinmed/forskning/sentre/nssf/ forebygging/chatsafe/index.html

Følg \#chatsafe på Instagram: https://www.instagram.com/chatsafe_no/

Veilederen er utviklet av det australske forskningssenteret Orygen med støtte fra den australske regieringen og og tilpasset for norske forhold av Nasionalt senter for selvmordsforskning og -forebygging (NSSF).

For ungdommer er lærere ofte personer de har tillit til, og det er mulig å diskutere selvmord i klasserommet på flere måter. Elevene kan for eksempel ta kontakt med lærere for å snakke om sine egne (eller noen andres) selvmordsrelaterte tanker, følelser eller atferdsmønstre. Lærere kan også bli oppmerksom på elever som er med i diskusjoner på nettet, eller som ser på innhold om selvmord på sosiale medier. Emnet selvmord kan også dukke opp i skolestiler, filmer eller i mediene hvis en kjent person dør av selvmord.

\#chatsafe for lærere ble opprettet for å giøre det enklere for lærere å gi råd til ungdommene de har kontakt med, om hvordan de kan snakke trygt om selvmord på sosiale medier. Ressursen inneholder informasion om hvordan lærere kan utforme trygt språk når de snakker om selvmord og giøre ungdommene i stand til å engasjere seg i selvmordsrelatert innhold på sosiale medier på en trygg måte. Denne ressursen inneholder også direktelenker til innhold på sosiale medier som er utformet av ungdommer, som lærere kan dele eller diskutere med elevene.

\#chatsafe-innhold er utviklet for personer mellom 16 og 25 år, men informasjonen i ressursen kan tilpasses

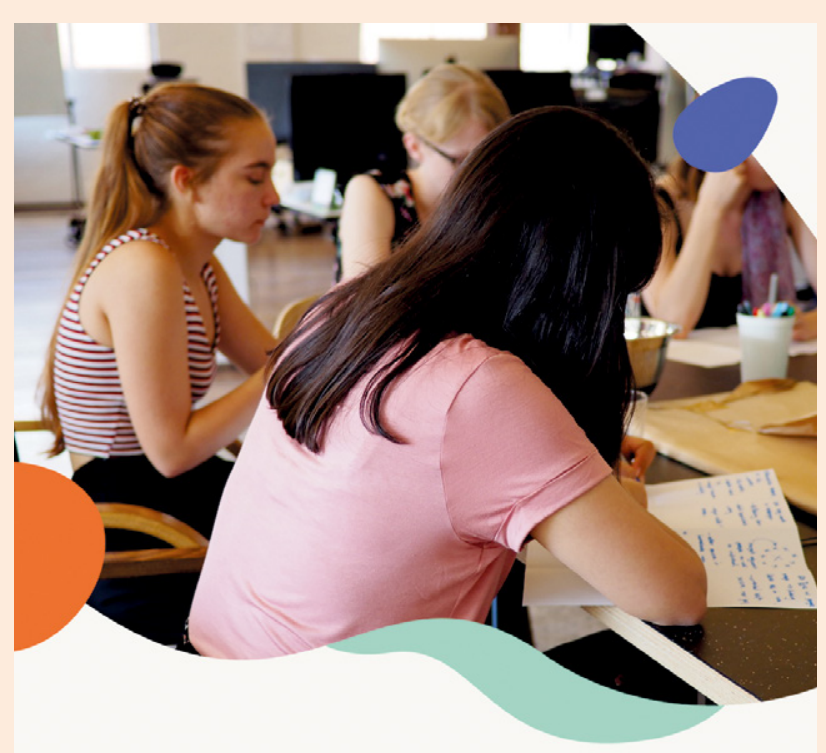

\section{\#chatsafe}

etter alderen på elevene. Lærere bør vurdere alderen på elevene når de diskuterer \#chatsafe-innhold.

I \#chatsafe for lærere finner du direktelenker til \#chatsafe-nettstedet og Instagram-siden til \#chatsafe. Det er også inkludert animasjoner rettet mot ungdom som tar for seg emnene som presenteres i ressursen. Lærere kan dele disse med elevene eller bruke videoene som samtalestartere.

I mai 2020 ble \#chatsafe-retningslinjene Veiledning for ungdom om å kommunisere trygt om selvmord på nettet lansert i Norge. Disse retningslinjene er utviklet av Orygen, oversatt og tilpasset til norske forhold av NSSF. Psyktærlig (www.psyktaerlig.no) har bidratt med sin erfaringskompetanse og kjennskap til målgruppen.

Mer informasjon om \#chatsafe og oversikt over ressurser finnes på Orygen sin nettside: https://www.orygen.org.au/chatsafe. 